Vol.3, Issue.2 pp.34-46, 2021

\title{
Barriers to Career Advancement in the Hotel Industry in Timor-Leste: Study of Gender Stereotyping, Old Boys' Network and Gender Differences
}

\author{
Helio Brites da Silva ${ }^{1}$, Vimolwan Yukongdi ${ }^{2}$, Finia Ribeiro ${ }^{3}$ and Elisabeth Barreto ${ }^{4}$ \\ 1, 3, ${ }^{4}$ Lecturers of the School of Tourism and Hospitality, Dili Institute of Technology, Dili Timor-Leste \\ ${ }^{2}$ Asian Institute of Technology, Bangkok, Thailand \\ Email: heliobrites11031980@gmail.com,vyukongdi@ait.asia,finiaribeiro2@gmail.com,baretoelizabeth89@gmail.com
}

\begin{abstract}
The hotel industry in Timor-Leste is female-dominated. However, women are under-represented in managerial and senior executive positions. This study examines the relative importance of gender stereotyping and old boys' network variables as barriers that impact women's and men's career advancement in the hotel industry in Dili, Timor-Leste. A survey questionnaire was distributed at 20 hotels in Dili, TimorLeste, and 16 hotels granted approval, represented by 385 individuals ( 226 women and 159 men). These data were analyzed using structural equation modeling. The results from this study indicated that gender stereotyping had a significant influence as a barrier to career advancement. Old boy's network which refers to informal system in which men who went to the same school or university help each other find jobs or get other social advantages had no significant barrier to the career advancement for both in women versus men comparison. Furthermore, the male group scores higher than the female group in the variables of stereotyping in gender differences analysis as the higher scores represent the biases against women. This study is the first study to examine barriers for individuals' career advancement in the hotel industry of Dili, Timor-Leste. This study suggests theoretical and practical implications on barriers for men's and women's career advancement and mitigates gender inequality in the organization.
\end{abstract}

Keywords: Gender differences, Hotel, Career advancement, Gender stereotyping, The old boys' network.

\section{Introduction}

Career advancement defines as the upward advances of employees' careers, which refers to employees who could advance by moving from their current level to a superior level (Brites et al., 2021; Jauhar \& Lau, 2018; Ting et al., 2020). In terms of employees' gender, women are seldom endorsed to the uppermost level or under-represented in management level in organizations (Catalyst, 2019: Powell \& Greenhaus, 2010; Thomas et al., 2018). Women are rarely denied chances merely because of their gender (Acker, 2004). This critical issue is faced by many organizations worldwide, in which the majority of the employees are women (Mišić-Andrić, 2015; Mooney \& Ryan, 2009); thus, this issue is essential for further investigation.

Previous studies have commonly found that only a few female employees are at the management level. The hotel industry is no exception. A Castell report (2017) indicated that male workers are likely to be endorsed to the principal/partner or highest level (Beck, 2018; Castell project, 2017). Although studies have been conducted in other countries to explore the reasons for women's underrepresentation in the hotel industry, the current study is the first to address this particular issue in the context of TimorLeste.

The following is the brief information regarding TimorLeste's cultural values or norms and male-dominated society which limit professional advancement for female employees. Timorese has a patriarchal cultural system, and men are expected to be responsible and major earners in the family. Also, the inherited custom of bride price (ADB, 2016) plays an essential part in professional development because of that; culturally, women are considered housewives after marriage and taking care of their family. That is, culturally Timorese live in a male-dominated society. Even though people's minds are set that men are more dominant than women in becoming managers, this situation should be changed. As also highlighted in the National Strategic Development Plan of Timor-Leste (SDP, 2011-2030) and a previous study in tourism done by Freitas et al., (2016). Therefore, gender equality in Timor-Leste should be further investigated.

The barriers to career advancement should be understood. Prior studies have provided evidence that these factors of gender stereotyping and old boys' networks could be barriers to career advancement. The remainder of this paper is structured as follows. The second section reviews the literature relating to prior research on the barriers to career advancement. Then, it is followed by hypothesis development and the conceptual framework of the study. The fourth section presents the methodology, including data collection, questionnaire development, and data analysis. The last section discusses the results and concludes with some implications of the research findings.

\section{Theoretical Background, Hypotheses Development and Hypothesized Model}

2.1 Theoretical Background

2.1.1 Career Advancement 
Career advancement refers to the extent to which employees perceived that they have clear opportunities within the organization and also defined in terms of occupational level, salary, the number of subordinates, and the number of promotions that an individual had obtained (Metz, 2003; Nasurdin et al., 2014; Tharenou, 2005). Furthermore, career advancement is associated with the opportunity for employees to perform more significant tasks, shoulder greater responsibilities, and have more autonomy at work (Chang \& Gong, 2008). In addition, career advancement allows employees to learn new skills and experiences associated with a new position.

Considerable evidence has accumulated related to the barriers to career advancement. A review of the career advancement literature (e.g., Metz, 2003; Ragins \& Sundstorm, 1989; Tharenou, 1994) has identified several category variables that influence career advancement barriers. The most commonly investigated influences are lack of training (Bashir et al., 2020; Minett et al., 2009). Also, there are demographic factors, such as marital status (Schneer \& Reitman, 2002), the number of children (Schneer $\&$ Reitman, 2002), and job market constraints and lack of confidence as barriers appear strongly to the career advancement.

Although these influences have provided essential insights into career advancement barriers, further development is possible in this aspect. Previous studies on career advancement in the hotel industry have mainly been conducted in Western countries only (Garavan et al., 2006; Jani \& Han 2013; Yoo \& Gretzels, 2011) and rarely in Southeast Asian countries. Thus, the current study will identify the barriers to career advancement in the hotel industry in Dili, Timor-Leste. Moreover, this research will investigate gender stereotyping and old boys' networks and how they affect barriers to career advancement. The following section explains the gender stereotyping and old boys' network and the subsequent hypothesis development.

\subsubsection{Gender Stereotyping}

Gender refers to being either male or female and the physical and social conditions of being male or female (Roger, 2017; Rublee et al., 2020). Also, a stereotype is a set idea, a fixed and over-generalized belief about a particular group or class of people (Roger, 2017). Furthermore, the gender stereotype is defined as a generalized view of preconception about the roles that are to be possessed or performed by women and men (Ellemers, 2018). Also, a gender stereotype is harmful when it limits women's and men's capacity to develop their abilities, pursue their careers, and make choices about their lives (Ellemers, 2018). Therefore, it is essential to narrow or limit Gender stereotyping.

Moreover, stereotype in the organization means any thought widely adopted in the organization. In this regard,
Timor-Leste is a country that is culturally male dominant. The culture is influenced by more than 500 years of Portugal's colonization, and there is a lack of perception working in hospitality management. People tend to consider it inappropriate, especially for women working at hotels during night shifts. Moreover, it is also mentioned by Poulston (2008) that women working in hotels would be subject to high levels of sexual harassment. Guests and peers usually approach them. It happens as women working in hotels are considered a low category job due to their level of literacy. I (a researcher) also worked in the hotel industry for five years and experienced similar negative attitudes towards female colleagues from guests and peers. There are rumors propagated in our society as well, targeting women working at hotels. All these adverse circumstances can be easily exploited, such as getting involved in relationships with the guests and tends to lead to gender stereotyping.

Additionally, Sirven and Debrand (2012) also mentioned that the concept of social capital could explain a person's standing reputation in the organization depending on the social network. When society creates stereotypes in one community, it usually influences women in their managerial advancement. Hence, the sexualization of work in Hotel Catering and Tourism (HCT) has a much broader presence. For example, compared to other industries, cruise line service employees were, historically, stereotyped. Moreover, sexualized roles need to comply with the expectations of some customer market segments.

Furthermore, it is mentioned that unskilled or semiskilled women tend to work in the most vulnerable jobs. They are more likely to experience poor working conditions, inequality of opportunity and treatment, violence, exploitation, stress, and sexual harassment (Baum, 2013). Thus, it is proposed that:

H1. Societal gender stereotyping would be a barrier to career advancement.

\subsubsection{The old boy's network}

The old boy's network literary means how men who have been to the same expensive school or university help each other find good jobs (Preece, 2017). Moreover, it is defined as the informal system in which men who went to the same school or university help each other find jobs or get other social advantages.

In male-dominated organizations, this term usually is always at the back of employees' minds. According to Chandrashekaran et al., (2020) and Guerrier (1986), the need for female hotel general managers to fulfil the necessary element of the job, women are trying to blend in with male norms. Previous studies mentioned that the Old Boy Network has substantially influenced women's managerial advancement (Elliott and Smith, 2004; Rublee et al., 2020). Women are always referred to as the "Old Boy Network" or the "Old Boy Club." It had varied meanings and a distinct 
impact on women's careers. Participants in all age groups recognized different aspects of the old boy network as problematic for women.

Furthermore, according to Mooney and Ryan (2009), most of the interviewees mentioned the strength of the old boys' network. They described it as a typical attitude among many male managers, particularly at the senior management level. It is referred to as a shared background, history, and mindset with informal networks that were not easily accessible by women. In addition, Chandrashekaran et al., (2020); Burke and Ng (2006) and Rublee et al., (2020) illustrated that organizational factors also impact women's career progression. Therefore, the main idea of this study would be focused on the regulatory aspect, as mentioned above regarding The Old Boy Network.

Moreover, based on the traditional practice, Timorese women cannot inherit or own properties (UNIFEM, 2015). Therefore, it is seldom trusted by women to govern organizational responsibilities. The only phenomenon differentiating Timorese from other Southeast Asian countries is 30 female representatives in the national parliament from 2002. Although women are well represented in the parliament, their voices are barely considered, as one of the women parliamentarians mentioned. Therefore, in the hotel industry, it is still infrequent that women occupy managerial positions. Thus, it is proposed that:

H2. The old boy's network would be perceived to be a barrier to career advancement.

\subsection{Hypothesized Model}

The hypothesized model for the present study is illustrated in Figure 1. The model depicts the two hypothesized relationships among independent variables of gender stereotyping and old boy's network as barriers to career advancement as the dependent variable. This hypothesized model developed for the present draws upon previous studies by Tharenou (2005), Allen et al. (2016), and Helitzer et al. (2016) on women's and men's career advancement.

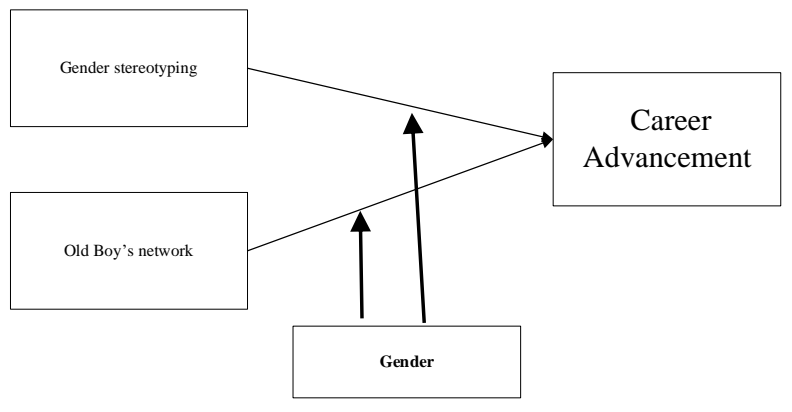

\section{Methods}

The sample size is based on the total number of hotel employees in Timor-Leste's capital city of Dili (based on the Timor-Leste government statistics survey in 2015; Lopes, 2015). The sample size is calculated using the formula of Yamane (1973), with a 95 per cent confidence level. The sample size of this study is 385 .

This study used a questionnaire as a survey tool to collect data from the participants and consisted of three main parts. The first part was demographic information, such as gender, age, marital status, educational background, and work experience. The dependent variables were functional level, salary, number of subordinates, and number of promotions. The second part consisted of old boys' network variables that focused on five main questions. The third part included Gender stereotyping that concentrated on the eight main questions. These variables (in the second and third parts of the questionnaire) were measured using a scale ranging from 1 ("strongly disagree) to 5 ("strongly agree").

The questionnaire was translated into Tetun (national language of Timor-Leste), as it is the back translation technique to ensure equivalence (Brislin, 1970). Back translation involved translating text that has already been translated back to its original language again to test the quality and accuracy of the original translation.

Data collection was conducted by contacting each hotel and obtaining an agreement to survey their employees. The hotel employees were asked to complete the questionnaire. As stressed in the cover letter, participation was voluntary, anonymous, and no compensation was provided. The pilot test was conducted to ensure that the questionnaire was understood and tested for reliability and factor analyses. A total of 16 top hotels granted approval to survey their employees. A self-administered questionnaire was distributed to 450 hotel employees in Dili. Out of 385 respondents who complete the survey, 226 are women, and 159 are men.

The dependent variable career advancement (CAD) was the mean of four items $(\alpha=0.774)$ assessing the respondents' functional level, salary, number of subordinates, and number of promotions (Metz, 2003; Tharenou et al., 2005). These four items were part of standardized questions and were analyzed to figure out the z-score. Since these four items had different response categories, they were standardized before averaging to form a score. Principal factor analysis supported the construct and discriminant validity of three elements of measuring women's and men's career advancement.

Only one societal factor called Gender stereotyping was measured based on three elements as illustrated by Baum T (2013); Poulston (2008); and Mooney and Ryan (2009). Some of the example questions asked to the respondents were "Managers of the hotel should be men," "Men are in charge of the organizations," and "Men make better leaders

Figure 1. Hypothesized Model 
Vol.3, Issue.2 pp.34-46, 2021

Available online at: https://tljbm.org/jurnal/index.php/tljbm

than women." The responses were captured on a 5-point scale averaged and satisfactory accepted with $\alpha=0.853$.

\subsection{Old boy's Network}

Initially, five elements were considered to measure the old boy's network. However, as the factor analysis method recommended, one element was deleted to get Cronbach alpha below 0.70 . Therefore, the mean of four elements was calculated as $\alpha=0.74$ in this study based on the previous findings (Datta \& Argawal, 2017; Mooney \& Ryan, 2009). Some of the example questions asked to respondents were "Women are not invited to join men's group," "I have seen in this organization many great women were overlooked for promotion while men with less experience were promoted." The responses ranged in a 5-point scale from 1-strongly disagree to 5 -strongly agree.

The independent variables with their abbreviations, means, standard deviations, reliabilities, and component matrixes are further explained in Table 2 in the result section.

\subsection{Analytical Strategy}

The analytical strategy mainly follows the widely recommended three-step approach of structural equation modeling (SEM; Arbuckle, 2010). The first step, which is exploratory factor analysis (EFA), validated the group constructs. The second step, which is confirmatory factor analysis (CFA), validated the overall measurement model. Lastly, SEM tested the proposed structural model specifying the relations between constructs. SEM was used to test the effects of the ten predictor variables on the dependent variable (i.e., career advancement).

The goodness of fit indices was used to assess the fit of the measurement and structural models. The relative chisquare compares the observed matrix with the estimated matrix. The chi-square divided by its degrees of freedom (CMIN/DF) is a means to assess model fit. A relative chisquare ratio of under 2 or 3 indicates an acceptable model fit (Arbuckle, 2010). The root means the square error of approximation (RMSEA) index constitutes a measure of parsimony describing the discrepancy between the observed and estimated covariance matrices per degree of freedom. RMSEA values below 0.08 are considered a good fit (Arbuckle, 2010).

\section{Results}

The table 1 briefly explains the profile of the respondents. The demographic of respondents showed that out of the 385 sample respondents from 16 hotels, 59\% were female, $41 \%$ were male, $54 \%$ were married, and $43 \%$ were single. Moreover, with $47 \%$ of respondents who attained high school. $33 \%$ of the respondents have a year of working experience, with $85 \%$ operational.
Table 1. Sample Characteristics

\begin{tabular}{|lcccc|}
\hline $\begin{array}{l}\text { Demographic } \\
\text { information }\end{array}$ & Females & \multicolumn{2}{c|}{ Males } \\
\hline Gender & 226 & 59 & 159 & 41 \\
\hline & & & & \\
\hline Age & & & & \\
\hline $\mathbf{1 9 - 3 0}$ & 162 & 42 & 103 & 27 \\
\hline $\mathbf{3 1 - 4 0}$ & 46 & 12 & 36 & 9 \\
\hline $\mathbf{4 1 - 5 0}$ & 16 & 4 & 13 & 3 \\
\hline $\mathbf{5 1 - 6 0}$ & 2 & 1 & 6 & 2 \\
\hline Over 61 & & & 1 & 0 \\
\hline
\end{tabular}

\begin{tabular}{|lcccc|}
\hline Status & & & & \\
\hline Single & 85 & 22 & 83 & 22 \\
\hline Married & 133 & 35 & 74 & 18 \\
\hline Divorce & 4 & 1 & 1 & 0 \\
\hline Separated & 2 & 1 & 1 & 0 \\
\hline Widow & 2 & 1 & & \\
\hline Educational level & & & & \\
\hline Primary school & 1 & 0 & 3 & 1 \\
\hline Secondary school & 6 & 2 & 6 & 2 \\
\hline $\begin{array}{l}\text { High school } \\
\text { Hotel training and } \\
\text { certificate }\end{array}$ & 106 & 28 & 73 & 18 \\
\hline $\begin{array}{l}\text { Diploma 3 } \\
\text { (Bacherelato) }\end{array}$ & 43 & 11 & 28 & 7 \\
\hline Bachelor's degree & 22 & 6 & 16 & 4 \\
\hline Master's degree & 48 & 12 & 30 & 8 \\
\hline \begin{tabular}{l} 
PhD \\
\hline
\end{tabular} & & & 3 & 1 \\
\hline
\end{tabular}

\begin{tabular}{|lcccc|}
\hline Occupational level & & & & \\
\hline Operational level & 195 & 51 & 135 & 35 \\
\hline Supervisor level & 24 & 6 & 13 & 3 \\
\hline Executive level & 7 & 2 & 11 & 3 \\
\hline
\end{tabular}

\begin{tabular}{lcccc|}
$\begin{array}{l}\text { Work experience (in } \\
\text { years) }\end{array}$ & & & & \\
\hline Under 1 month & 4 & 1 & 3 & 1 \\
\hline 2-11 months & 36 & 9 & 29 & 8 \\
\hline 1 year & 78 & 20 & 49 & 13 \\
\hline 1-9 years & 98 & 25 & 66 & 17 \\
\hline Over 10 years & 10 & 3 & 12 & 3 \\
\hline
\end{tabular}


Then, they are $10 \%$ at the supervisor level and $5 \%$ at the executive level. In addition, according to Table I, the majority, 195 out of 385 respondents representing $51 \%$ of the total respondents, are female. However, the managers mostly are men, such as 11 male and seven female managers in the surveyed 16 hotels in this study. Therefore, even though women in Dili, Timor-Leste dominate the hotel industry, women are still underrepresented at the executive levels.

Table 2. Means, Standard Deviations, and Scale Reliabilities

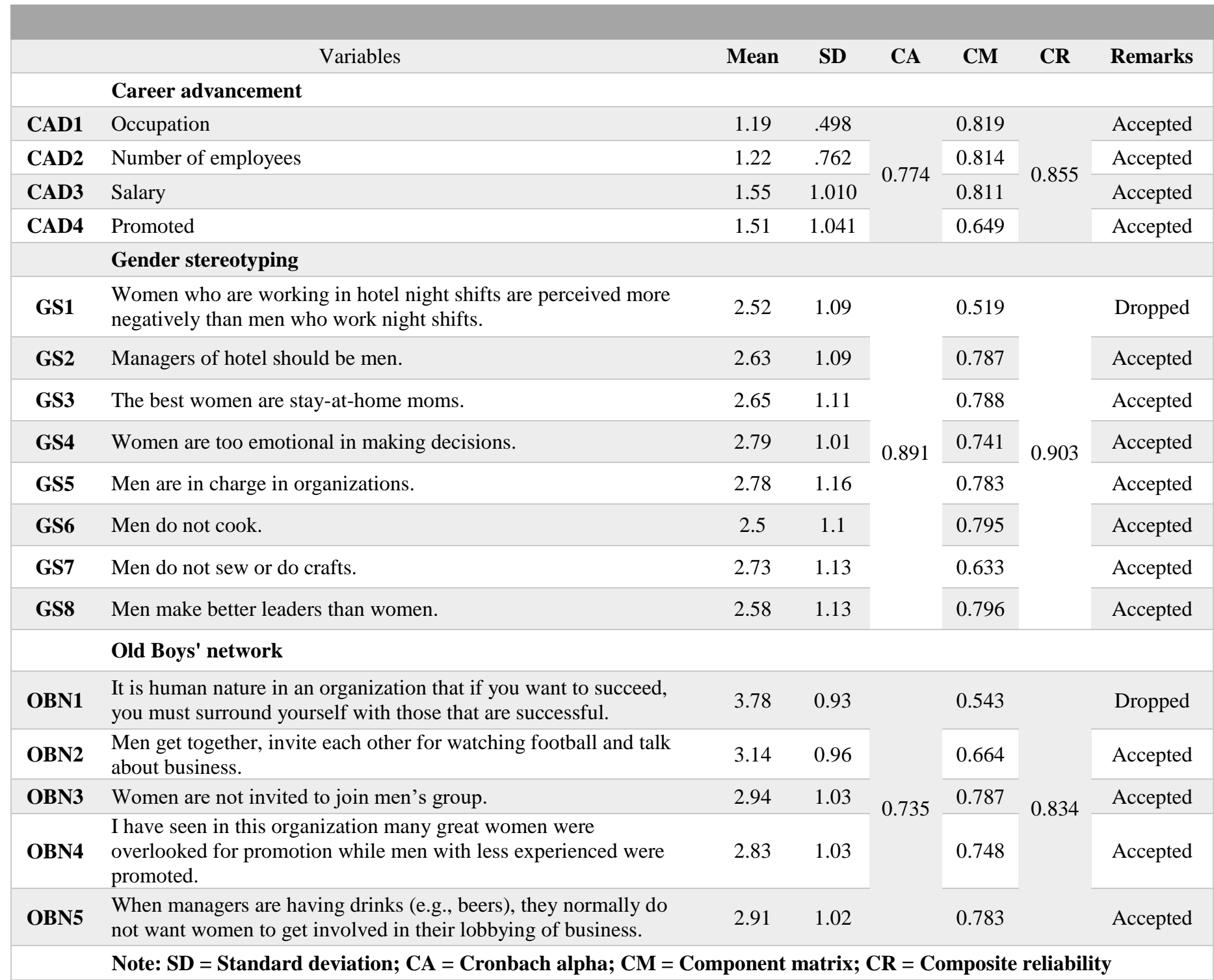

\subsection{Measurement Model}

\subsubsection{Exploratory Factor Analysis}

First, the Kaiser-Meyer Olkin (KMO) sampling adequacy and Barlett's Test of Sphericity measures were used to examine the exploratory factor analysis (EFA). The Chisquare value is 2691.38 with 105 degrees of freedom, a significant 0.00 , representing a sufficient correlation among variables to proceed. The KMO measure of sampling adequacy is 0.87 , more significant than 0.50 (Hair et al., 2018). Hence EFA is considered an appropriate technique for further analysis of the data. 
Vol.3, Issue.2 pp.34-46, 2021

Available online at: https://tljbm.org/jurnal/index.php/tljbm

The principal component analysis method and rotated component matrix are used to identify the items under each factor in EFA. Table 2 presents the factor loadings and the reliability of each construct. All the factor loadings vary between 0.60 and 0.80 , higher than the minimum acceptable factor loading of 0.60 (Hair et al., 2018). Table 2 illustrates that the two items were dropped due to their low factor loadings $(\leq 0.60)$, they are (GS1 and OBN1) as component matrix loading as 0.52 , and the remaining items were retained and used for the next phase of the analysis.

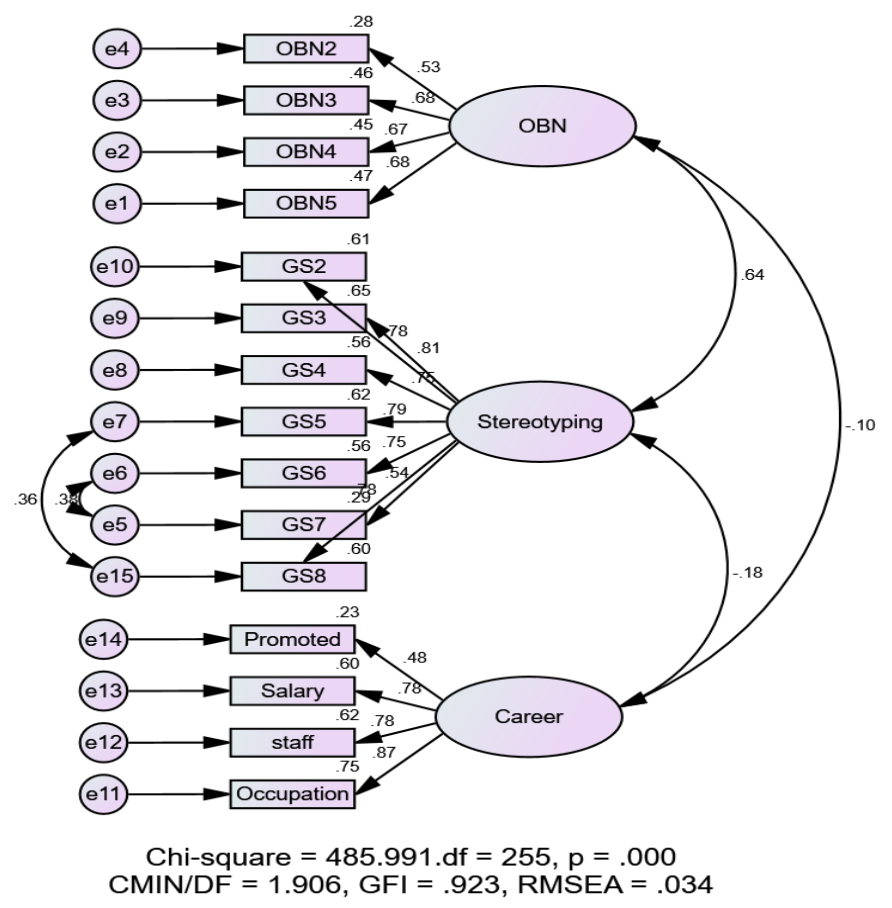

Figure 2. Measurement Model for Career Advancement

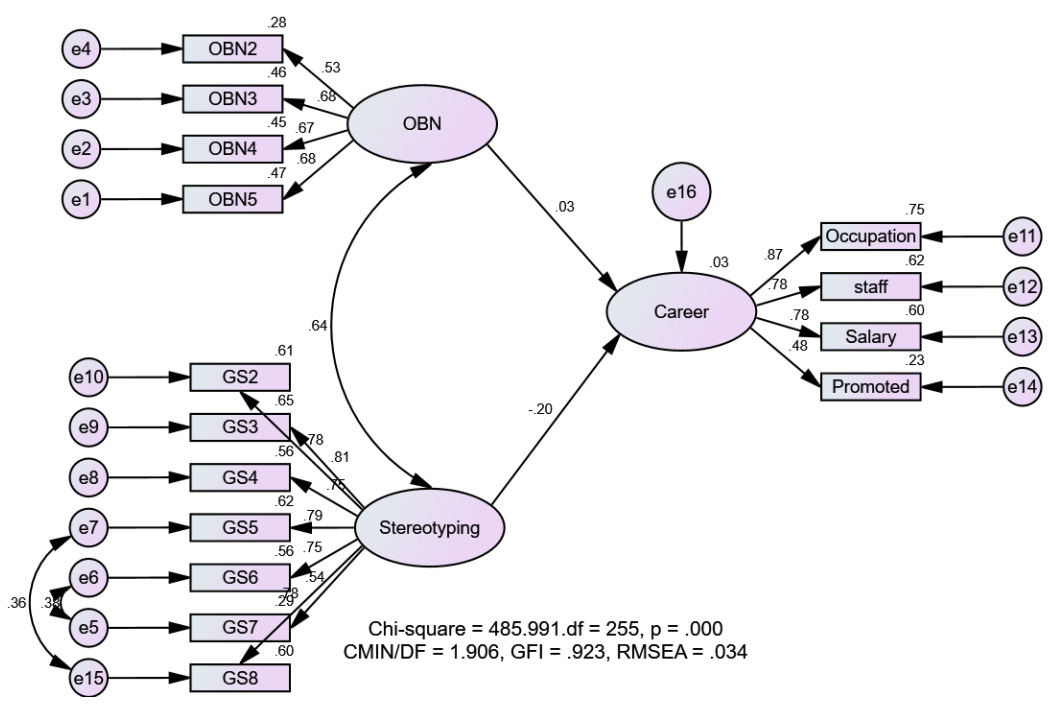

Figure 3. Structural Model 
Table 3. Results of the Tested Hypotheses for the Combined Sample

\begin{tabular}{|ccccc|} 
Hypotheses & Relationships & $\begin{array}{c}\text { Standardized } \\
\text { Path } \\
\text { Coefficients }\end{array}$ & Results & $\begin{array}{c}\text { Significant } \\
(\boldsymbol{p})\end{array}$ \\
\hline $\mathbf{H 1}$ & G. Stereotyping $\rightarrow$ CAD & -0.202 & Supported & $* *$ \\
\hline H2 & Old boy's network $\rightarrow$ CAD & 0.030 & Not Supported & 0.739 \\
\hline
\end{tabular}

Notes: $N: 385, * *=p<0.05 ; C A D=$ Career advancement

\subsubsection{Confirmatory Factor Analysis}

Confirmatory factor analysis of each factor, along with standardized factor loadings, is evaluated (see Figure 2). The test result was the same as the model adaptability standard suggested by Arbuckle (2010) and mentioned in the goodness model of fit. The test result was $\chi^{2}=485.911, \mathrm{df}=$ $255, \mathrm{CMIN} / \mathrm{DF}=1.906$, GFI (goodness of fit index) $=0.923$, CFI $($ comparative fit index $)=0.956, p$-value $=.000$, RMSEA (root mean square error of approximation) $=0.034$, NFI (normed fit index) $=0.913$ as shown in Figure 2 above. Overall, the maximum likelihood estimates for the covariance of OBN and GS are positively significant $(\beta=$ $0.641)$, and GS and CAD are negatively significant $(\beta=-$ $0.182)$. Therefore, these two variables are correlated and would be the barrier to career advancement.

\subsubsection{Structural Model}

Structural Equation Modelling (SEM) is a model to explain the influences or effects of latent variables (factors) on other latent variables (items) in the model (Arbuckle, 2010). Then the model was analyzed using AMOS statistical software. The output showed that this model meets the thresholds requirements for model fit indices see Table II of Arbuckle (2010). The test result was $\chi^{2}=485.911, \mathrm{df}=255$, $\mathrm{CMIN} / \mathrm{DF}=1.906$, GFI (goodness of fit index $)=0.923, \mathrm{CFI}$ $($ comparative fit index $)=0.956, p$-value $=.000$, RMSEA (root mean square error of approximation $)=0.034$, NFI (normed fit index $)=0.913$ as shown in Figure 3 . Thus, the model is well-fitted. The research hypotheses were tested according to the outputs of the structural model. The results of the test are presented in Table 3.

The following is the test for differences between women and men based on the structural model. The study's objective is to examine the relative importance of gender stereotyping and old boys network variables as barriers impact women's and men's career advancement.

\subsection{The gender Differences Analysis \\ 4.2.1. Male sample}

Figure 4 shows that the model's independent variables explain 74 percent of the dependent variable variance. In the male group the two variables are not significant in their standardized estimates weight, such as gender stereotyping ( $\beta=-0.184, p$-value $=0.129)$, an old boy's network $(\beta=-$ $0.027, p$-value $=0.828)$. In this male group sample, both variables have no direct impact on career advancement. The model was appropriate. The results tested according to the outputs of the structural model for the male sample are presented in Table 4.

\subsubsection{Female Sample}

Figure 5 illustrates that 75 percent of occupation level. The variables of gender stereotyping $(\beta=-0.243, p$-value $=$ 0.048 ) had a negatively significant to the CAD and old boy's network $(\beta=0.086, p$-value $=0.503)$ had no significant to $\mathrm{CAD}$ in standardized estimates weight.

Therefore, based on results obtained from the considered male and female sample groups (Figure 4 and Figure 5), it can be summarized that exogenous variables influence similarities and differences. The similarity is that the old boys' network had not significant as the barriers to career advancement. Furthermore, the difference is gender stereotyping in the male group was not effective as a barrier to career advancement; however, in the female group, it had negative significance to career advancement. This means the male group did not pay attention clearly to generalizing stereotypes or they still think that male is a domain in the organization as leaders or superior.

\section{Discussions}

This study aimed to identify the relative importance of gender stereotyping and the old boy's network as barriers to career advancement in the hotel industry. The objective was to increase the understanding regarding the underlying reasons for the under-representation of women at the management level and their career advancement. The result of hypothesis testing using structural equation modeling (SEM) is discussed in the following sections.

Gender stereotyping was negatively related to career advancement (see Table 4 and Table 5). The result showed the negative significance of gender stereotyping in the female group (see Table 5). This means women have a concern about Gender stereotyping against them in the hotel industry. This result is consistent with Heilman (2012) and 
Vol.3, Issue.2 pp.34-46, 2021

Available online at: https://tljbm.org/jurnal/index.php/tljbm

Rublee et al., (2020) which her study found that its central argument is that gender stereotypes give rise to biased judgment and decisions, impeding women's career advancement (Chandrashekaran et al., 2020; Heilman, 2012). Also, it is consistent with the findings in Poulston (2008) and Baum (2013) that women are usually understereotyped in the organization, particularly in the hotel industry. Therefore, gender stereotyping must be paid attention, and be narrowed down or omitted in practice in every organization. As a result, gender equality will be standing for.

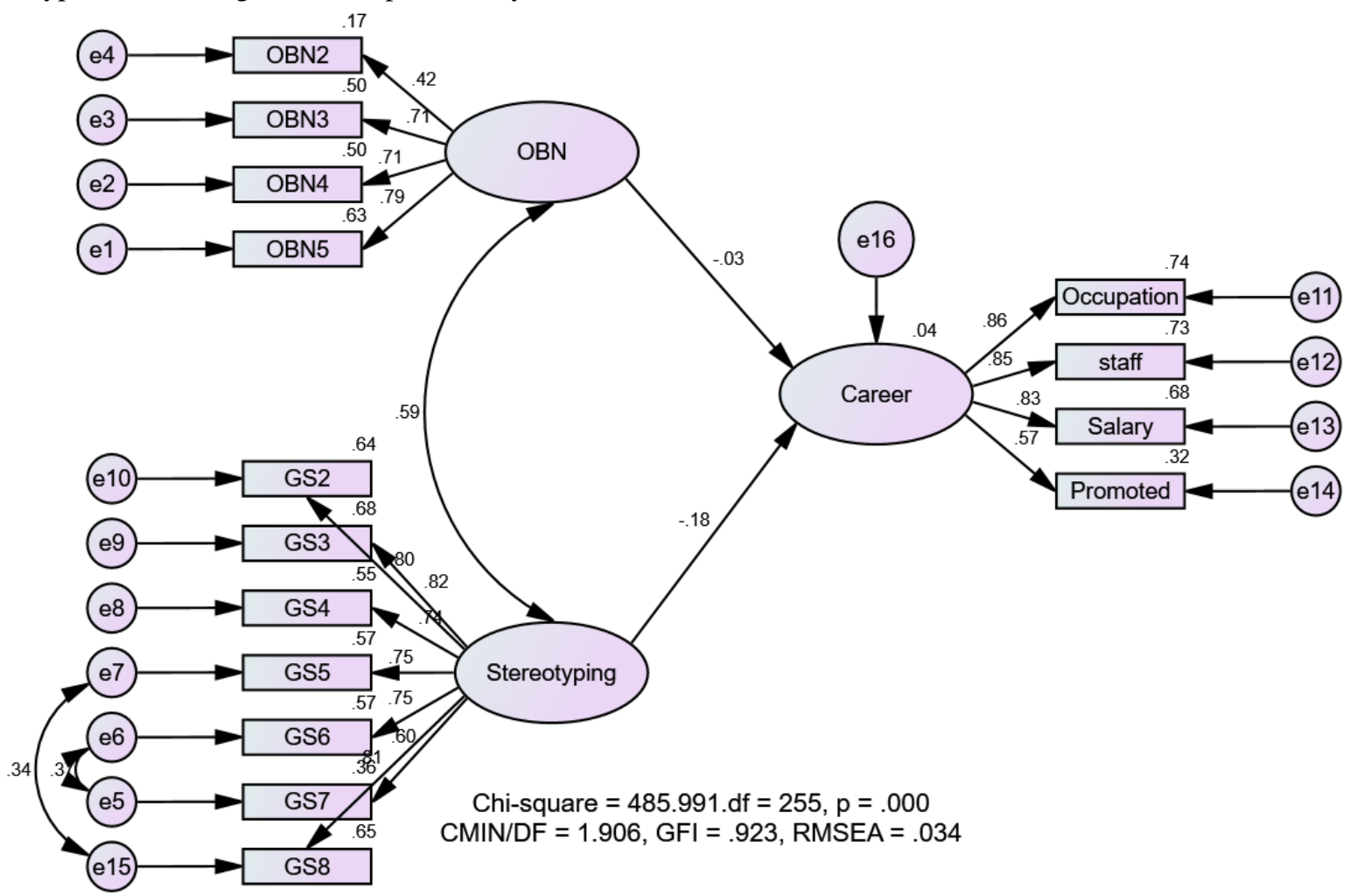

Figure 4. Model Fit for Male Sample

Table 4. Results of the Hypothesis Testing for the Male Sample

\begin{tabular}{|c|c|c|c|c|}
\hline Hypotheses & Relationships & $\begin{array}{c}\text { Standardized Path } \\
\text { Coefficients }\end{array}$ & Results & Significant $(p)$ \\
\hline H1 & G. Stereotyping $\rightarrow$ CAD & -0.184 & Not Supported & 0.129 \\
\hline $\mathbf{H 2}$ & $\mathrm{OBN} \rightarrow \mathrm{CAD}$ & -0.027 & Not Supported & 0.828 \\
\hline
\end{tabular}


Vol.3, Issue.2 pp.34-46, 2021

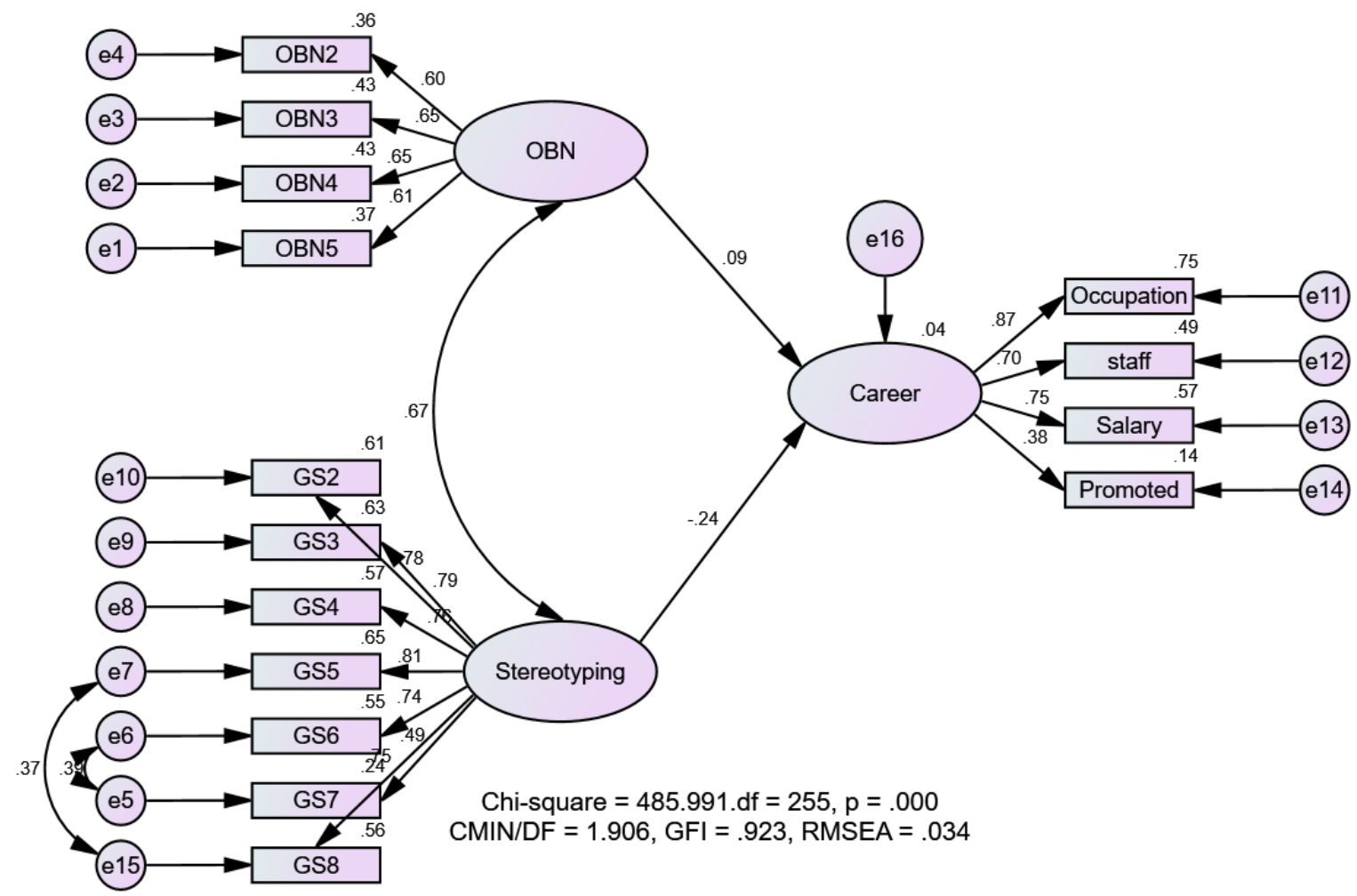

Figure 5. Model Fit for Female Sample

The results tested according to the output of the structural model for the female sample are presented in Table $\mathbf{5}$.

Table 5. Results of the Hypothesis Testing for the Female Sample

\begin{tabular}{|c|l|c|l|c|}
\hline \multirow{2}{*}{ Hypotheses } & \multicolumn{1}{|c|}{ Relationships } & $\begin{array}{c}\text { Standardized } \\
\text { Path } \\
\text { Coefficients }\end{array}$ & Results & $\begin{array}{c}\text { Significant } \\
(\boldsymbol{p})\end{array}$ \\
\hline H1 & G. Stereotyping $\rightarrow$ CAD & -0.243 & Supported & $* *$ \\
\hline H2 & OBN $\rightarrow$ CAD & 0.086 & Not Supported & 0.503 \\
\hline
\end{tabular}

Notes: $N=226 ; * * *=p<0.001 ; * *=p<0.05 ; C A D=$ Career advancement

On the other hand, the result did not show significance in the men group (Table 5). This means men ignore the generalized of women being stereotyped. The male group still believes that men should be the manager or domain in the organization. This result is consistent with the statement that "its central argument is that gender stereotypes give rise to biased judgment and decisions, impeding women's career advancement" (Heilman, 2012, p.57)." This is also consistent with Timor-Leste's patriarchal culture, which means that men should be leaders (UNFPA, 2017).
Further, it is consistent with the terms Timorese women cannot inherit or own properties (UNIFEM, 2015). Therefore, it is essential to have deeply understood for the hotel employees that every individual, including women, has the right to be a leader. As long as that woman has adequate qualifications to be a leader, why not be a leader. Thus, respecting human rights and gender equality is essential in every organization, especially the hotel industry as a women's industry. 
In addition, in the further analysis of gender differences, it was found that there are still differences between male and female phenomena in terms of gender stereotyping. The result can be seen in the mean scores for each variable. In the mean scores, the higher a participant scores in the three variables of gender stereotypes, the greater their bias against women. The mean results show that primarily male participants' scores are higher than those of female participants. This finding is consistent with Heilman's (2001) statement that it is essential to understand how gender stereotypes can prevent women from advancing within the organizational hierarchy - recognizing that top management and executive level jobs are almost always considered "male." The present study also found something similar: most hotel managers are men, 11 among 18 executive managers. Heilman (2001) and Rublee et al., (2020) also mentioned that because of gender bias and how it influences evaluation in work settings, being competent does not necessarily ensure that women will advance to the same organizational level as an equivalently performing man. Moreover, as cited in Napasri and Yukongdi (2015), gender stereotyping creates various forms of bias, e.g., in recruitment and selection, offering less-critical assignments to women, unequal development opportunities, and performance appraisal criteria and processes.

To determine if the phenomenon of gender stereotyping differs between the two participant groups, male and female, an independent t-test was conducted. The result indicated significant differences between male and female participants regarding gender stereotyping $(t=2.242 * *)$. Male participants scored $(\mathrm{M}=2.80, \mathrm{SD}=0.971)$ comparatively higher than female participants $(M=2.57$. $S D=0.989)$. In the present study, men tend to score higher in the gender stereotypes, which leads to gender bias against women. This result is similar to that of Chandrashekaran et al., (2020) and Mihalčová et al. (2015) regarding the effect of gender stereotypes resulting in low representation of women in the senior management. Therefore, it can be concluded that the existence of stereotypes still has a substantial influence on society. As mentioned in the background for the study, Timor-Leste has a patriarchal culture and society, and top management tends to be male-dominated.

The hypothesis $\mathrm{H} 2$, regarding the perceived barrier of the old boy's network, is not supported (see Table 3, 4, and 5). This result is inconsistent with Napasri and Yukongdi's (2015) and Rublee et al., (2020) findings, where they stated that the old boy's network forms a barrier to career advancement. Furthermore, Chandrashekaran et al., (2020) and Elliott and Smith (2004) said that male connections maintain a significant advantage in organizations. Male networks also tend to be composed of individuals who have a greater attachment to the labor market (Parks-Yancy, 2010). This means that those part of the old boy's network tends to have better career advancement. In Timor-Leste's hotel industry case, the old boy's network might not have been done yet as it is not common to have old boys' network in the hotel industry.

\section{Conclusions and Implications}

This paper demonstrates two main barriers factors of career advancement. The two factors refer to gender stereotyping and the old boys' network, which is commonly occurring in organizations, and it's impeded the individuals' career advancement. This study purposefully intended to examine factors of Gender stereotyping and old boys' network as the barriers to career advancement.

The results indicated that the barriers factors to career advancement are mostly from Gender stereotyping. This result strongly supports the idea that stereotypes such as those based on gender constitute an idea central to the present analysis. It is evident that male groups still do not pay attention to gender stereotypes, which are still happening across the organization, especially in the hotel industry. Men groups still believe that they are the domain in the organization, especially with the generalized words that men should be leaders, women should stay at home as moms, and women do not make better leaders. This should be narrowed down; if not us today, who else will conduct this. Gender equality must be stood for.

The predicted variables were chosen in this study based on the relevant previous surveys. It can be summarized that some variables used in the western countries can be used in Timor-Leste. Precisely, measurement scales indicated moderated level reliability and validity, and research findings were relevant to the prior studies conducted in the western context. As in Timor-Leste's case, the old boys' network is not happening much as it is a new country, and the interpretation for men to "eliminate masculine social traits," such as dominance, aggressiveness and forcefulness in order to promote gender equality might raise some eyebrows among the male population.

\subsection{Theoretical Implications}

This study's theoretical implications can be strengthened from two perspectives. First, this is one of the first studies that have tested some barriers factors on career advancement, particularly in the hotel industry in TimorLeste. Second, gender stereotyping and old boy's network might be evidence as barriers to career advancement. Therefore, for more future studies can extend this work by investigating these variables. This theory enables employees to know the barriers to their career advancement. Finally, Gender does matter, which means we cannot assume one size fits all-that-is one model includes both men and women. Thus, this might be a combination model study or these two models as references for identifying barriers related to career advancement in the hotel industry. 


\subsection{Practical Implications}

The present study offers several practical implications for the hotel industry's human resources management team and practitioners. First, by investigating gender stereotyping as the barrier to career advancement, the result indicated in the female group that gender stereotyping is negatively significant to career advancement. Depending on how career success is measured in an organization, different Gender stereotyping must be ignored to produce the most accurate selection system.

Second, the finding of this study has proved that the old boy's network does not play an essential role as a barrier to career advancement. It might be the limited number of Timorese as the owner of the hotels. Thus, there is no implementation for the old boy's network in the hotel industry. Also, hope for the future hotel development, the practices of the old boy's network would be omitted and narrowed down.

Finally, women are moving from one organization to another and seeking advancement opportunities. In this current era of global competition, hotel administration needs to understand that the barriers to women's career advancement force women to leave their jobs. In the end, the industry may lose talented female employees who might have extensively contributed to the industry.

\section{Limitations and Recommendations for Future Research}

The limitation of this study is the study only identifies some barriers variables on career advancement. The study has identified gender stereotyping as the main barrier to career advancement. There might be some other gender stereotyping variables that would have a negative effect on career advancement in the hotel industry. Several researchers have shown that social masculine stereotypical traits seem to be a significant risk factor for bullying perpetration in women's careers. This means men still must eliminate masculine social traits (dominant, aggressive, and forceful) to reduce dominance and power in favor of gender equality. Thus, it suggests for future studies to investigate the related variables of social masculine stereotypical traits.

Though the present study has boundaries, it has strengths also. The current study identified the barriers factors related to career advancement from female and male employees in the hotel industry in Timor-Leste. The two strength of this study is as follows. First, this is the first study of gender stereotyping that negatively affected hotel employees' career advancement in Dili, Timor-Leste. Thus, future researchers might use this as a model guide for future research on barriers to career advancement. Second, the old boy's network had no related barriers to career advancement in the hotel industry in Timor-Leste. Therefore, it might not be implemented in the hotel industry.
Furthermore, Timorese hotel employees and organizations could learn to guide barriers to developing and meeting hotel objectives and needs. Overall, the unanticipated gender stereotyping and old boy's networks as barriers to individual career development might vary through industries. Therefore, the industry-specific study is fruitful. Finally, this learning considered both females and males as a sample of this study which facilitated the gender differences analysis.

\section{References}

Acker, J., (2004), "Gender, capitalism and globalization," Critical Sociology, Vol. 30 No.1, pp. 17-41.

Acker, J. (2006). Inequality regimes: Gender, class, and race in organizations. Gender \& Society, 20(4), 441-464.

Allen, T. D., French, K. A., \& Poteet, M. L. (2016). Women and career advancement: Issues and opportunities.

Organizational Dynamics, 45(3), 206-216.

https://doi.org/10.1016/j.orgdyn.2016.07.006

Arbuckle, J.L. (2010). IBM SPSS Amos 19 user's guide. Crawfordville, FL: Amos Development Corporation, 635.

Asian Development Bank ADB, (2016), "Timor-Leste Country Gender Assessment," Retrieved from https://www.adb.org/documents/timor-leste-country-genderassessment (Accessed April 18, 2020).

Baum, T. (2013). International perspectives on women and work in hotels, catering, and tourism. Geneva: International Labour Organization.

Bashir, M. S., Haider, S., Asadullah, M. A., Ahmed, M., \& Sajjad, M. (2020). Moderated Mediation Between Transformational Leadership and Organizational Commitment: The Role of Procedural Justice and Career Growth Opportunities. SAGE Open, 10(2), 2158244020933336.

Beck G. (2018). Women in the hospitality industry battling gender inequality. Retrieved from https://broad.msu.edu/news/women-hospitality-industrybattling-gender-inequality/ (accessed June 15 2020).

Brislin, R. W. (1970). Back-translation for cross-cultural research. Journal of cross-cultural psychology, l(3), 185216.

Brites da Silva, H., Yukongdi, V., Kusakabe, K., \& Zimmermann, W. (2021). Career Advancement in the Hotel Industry in Timor-Leste: Study of Individual, Organizational, and Gender Differences. SAGE Open,11(3), 21582440211032683. 
Vol.3, Issue.2 pp.34-46, 2021

Available online at: https://tljbm.org/jurnal/index.php/tljbm

Burke, R.J. and Ng, E., (2006), "The changing nature of work and organizations: Implications for human resource management," Human Resource Management Review, Vol.16 No. 2, pp.86-94.

Chandrashekaran, S., Sanyal, D., Tripathy, S., \& Jain, T. (2020). Breaking through the Old Boys' Club. Economic \& Political Weekly, 55(4), 33.

Catalyst (2019), "Women in Management", https://www.catalyst.org/research/women-in-

management/(accessed January 25, 2020).

Castell Report. (2017). The castell project forms to assist the advancement of women professionals in the hospitality industry. Retrieved from https://www.castellproject.org/news/2017/2/28/womenamp-leadership-the-highland-groups-peggy-berg (accessed June 15 2020).

Chang, S. \& Gong, Y. (2008) Institutional antecedents and performance consequences of employment security and career advancement practices: Evidence from the people's republic of China. Human Resources Management, 47(1), 3348.

Datta, S., \& Agarwal, U. A. (2017). Factors affecting career advancement of Indian women managers. South Asian Journal of Business Studies, 6(3), 314-336. https://doi.org/10.1108/SAJBS-07-2016-0062

Ellemers, N. (2018). Gender stereotypes. Annual review of psychology, 69, 275-298.

Elliott, J. R., and Smith, R. A. (2004). Race, Gender and Workplace Power.

Freitas, J., Vong, M., \& Mendes, J., (Eds) (2016). Proceedings of the International Conference on Emerging Tourism Destination: Challenges and Opportunities, (ICETD 2016), Dili, Centre for Applied Research \& Policy Studies (CARPS) DIT.

Garavan, T.N., O'Brien, F., \& O'Hanlon, D. (2006). Career advancement of hotel managers since graduation: a comparative study. Personnel Review.

Guerrier, Y. (1986). Hotel manager an unsuitable job for a woman? The Service Industries Journal, 6(2), 227-240.

Hair, J. F., Black, W. C., Babin, B. J. \& Anderson, R. E, (2018). Multivariate Data Analysis. 8 ed. Andover, Hampshire: Cengage.

Heilman M. E., (2001). Description and Prescription: How Gender Stereotypes Prevent Women's Ascent Up the Organizational Ladder. Journal of Social Issues, 57(4), 657674. https://doi.org/doi:10.1111/0022-4537.00234
Heilman, M.E., (2012), "Gender stereotypes and workplace bias," Research in Organizational Behavior, Vol. 32, pp.113135.

Helitzer, D. L., Newbill, S. L. Cardinali, G. Morahan, P. S. Chang, S., \& Magrane, D. (2016). Narratives of Participants in National Career Development Programs for Women in Academic Medicine: Identifying the Opportunities for Strategic Investment. Journal of Women's Health, 25(4), 360-370, doi: 10.1089/jwh.2015.5354.

Jani, D., and Han, H. (2013), "Personality, social comparison, consumption emotions, satisfaction, and behavioural intentions: How do these and other factors relate in a hotel setting?", International Journal of Contemporary Hospitality Management, Vol. 25 No. 7, pp. 970-993, DOI: 10.1108/IJCHM-10-2012-0183.

Jauhar, J., \& Lau, V. (2018). The glass ceiling and women's career advancement to top management: The moderating effect of social support. Global Business and Management Research, 10(1), 163-178.

Lopes S. (2015). Timor-Leste in Figures 2015. Retrieved from http://www.statistics.gov.tl/wpcontent/uploads/2017/02/Timor-Leste-em-Numeros20151.pdf

Metz, I. (2003), "Individual, interpersonal, and organizational links to women's advancement in management in banks," Women in Management Review, Vol. 18 No. 5, pp. 236-251, DOI: $10.1108 / 09649420310485087$.

Minett, D., Yaman, H. R. and Denizci, B. (2009), "Leadership styles and ethical decision-making in hospitality management," International Journal of Hospitality Management, Vol. 28 No. 4, pp. 486-493.

Mihalčová, B., Pružinský, M., \& Gontkovičová, B. (2015). The Consequences of Gender Stereotypes in the Work of Managers. Procedia Economics and Finance, 23, 1260 1265. https://doi.org/10.1016/s2212-5671(15)00464-5

Mišić-Andrić, M. (2015), “Women's career advancement in organizations: Integrative framework for research," Journal of Engineering Management and Competitiveness, Vol. 5 No.2, pp. 102-107, DOI: $10.5937 /$ jemc $1502102 \mathrm{~m}$.

Mooney, S. and Ryan, I. (2009), "A woman's place in hotel management: upstairs or downstairs," Gender in Management: An International Journal, Vol. 24 No. 3, pp. 195-210, DOI: 10.1108/17542410910950877.

Napasri, T. and Yukongdi, V. (2015), "A study of Thai female executives: Perceived barriers to career 
advancement," Review of Integrative Business and Economics Research, Vol. 4 No. 3, p.108.

Nasurdin, A.M., Ahmad, N.H., \& Tan, C.L. (2014). Can career advancement and job security act as collateral for a commitment? Evidence from the hotel industry of Malaysia. International Journal of Social, Behavioral, Educational, Economic, Business and Industrial Engineering, 8(10), 3208-3214.

Parks-yancy, R. (2010). Equal Work, Unequal Careers : African Americans in the Workforce. Forum American Bar Association. Retrieved from https://scholar.google.co.th/scholar?hl=en\&lr=lang_en\&as_ $\mathrm{sdt}=0 \% 2 \mathrm{C} 5 \& \mathrm{q}=$ Parks-Yancy\%2C $+2010 \& \mathrm{btnG}=$

Poulston, J. (2008). Hospitality workplace problems and poor training: a close relationship. International Journal of Contemporary Hospitality Management, 20(4), 412-427.

Powell, G., \& Greenhaus, J. (2010). Sex, gender, and the work-to-family interface: exploring negative and positive interdependencies. Academy of Management Journal, 53: 513-534.

Preece, J. (2017). If party leaders want more women to run, they need to convince them that the "old boys' network" will support them too. USApp-American Politics and Policy Blog.

Ragins, B. R., and Sundstrom, E. (1989), "Gender and power in organizations: A longitudinal perspective," Psychological Bulletin, Vol. 105 No. 1, p. 51.

Roger, W. (2017). Key ConCept: GendeR. In Education Studies (pp. 46-52). Routledge.

Rublee, M. R., Jackson, E. B., Parajon, E., Peterson, S., \& Duncombe, C. (2020). Do You Feel Welcome? Gendered Experiences in International Security Studies. Journal of Global Security Studies, 5(1), 216-226.
Schneer, J. A., \& Reitman, F. (2002). Managerial life without a wife: Family structure and managerial career success. Journal of Business Ethics, 37(1), 25-38.

Sirven, N. and Debrand, T., (2012), "Social capital and health of older Europeans: Causal pathways and health inequalities," Social Science \& Medicine, Vol. 75 No. 7, pp.1288-1295.

Tharenou, P., Latimer, S., \& Conroy, D. (1994), "How do you make it to the top? An examination of influences on women's and men's managerial advancement", Academy of Management Journal, Vol. 37 No. 4, pp. 899-931.

Tharenou, P. (2005), “Does mentor support increase women's career advancement more than men's? The differential effects of career and psychosocial support", Australian Journal of Management, Vol. 30 No. 1, pp. 77-109.

Ting, W. M., Wai Chuen, E. P., \& Ahmad, N. B. (2020). A Study on Factors Affecting Career Advancement in Organization at Klang Valley. International Journal of Psychosocial Rehabilitation, 24(2).

Timor-Leste Strategic Development Plan (SDP) 2011-2030. Retrieved from http://timor-leste.gov.tl/wpcontent/uploads/2011/07/Timor-Leste-Strategic-Plan-201120301.pdf.

Thomas, R., Cooper, M., Konar, E., Rooney, M., NobleTolla, M., Bohrer, A., and Robinson, N. (2018), "Women in the Workplace 2018-Lean In and McKinsey \& Company", Hämtad från https://womenintheworkplace. com/doi, 10, 0045-3609. 